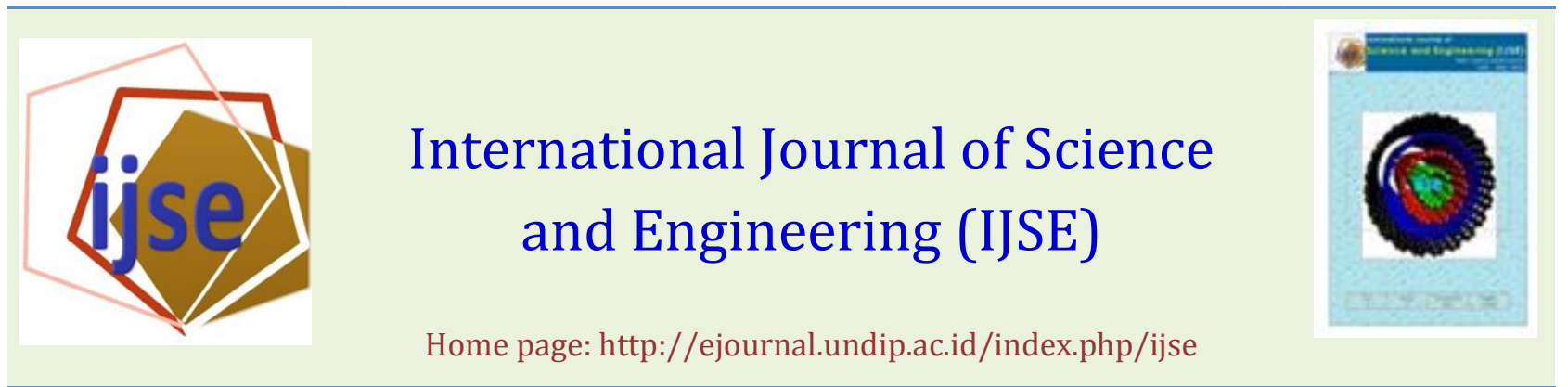

\title{
Assessment of Nelumbo nucifera and Hydrilla verticillata in the treatment of pharmaceutical industry effluent from 24 Parganas, West Bengal
}

\author{
Suman Mukherjee and Shamba Chatterjee \\ Department of Biotechnology, Haldia Institute of Technology, Haldia-721657, India \\ E-mail: shambac@gmail.com
}

\begin{abstract}
Modern day technologies employed in industrialization and unhygienic lifestyle of mankind has led to a severe environmental menace resulting in pollution of freshwater bodies. Pharmaceutical industry effluents cause eutrophication and provide adequate nutrients for growth of pathogenic bacteria. This study has been conducted with aquatic plants water lotus (Nelumbo nucifera) and hydrilla (Hydrilla verticillata) with an novel aim to treat pharmaceutical industry effluents showing the outcome of the experiments carried out with the effluents collected from rural areas of 24 Parganas, West Bengal, India. Determination of $\mathrm{pH}$, solid suspend, $\mathrm{BOD}_{5}, \mathrm{NH}_{3}-\mathrm{N}, \mathrm{MPN}$ and coliform test were used for this notioned purpose. Pharmaceutical waste effluent water treated with water lotus showed less $\mathrm{pH}$, solid suspend, $\mathrm{DO}, \mathrm{BOD}, \mathrm{NH}_{3}-\mathrm{N}$, MPN and coliform bacteria than hydrilla treatment when compared to the control. In conclusion, water lotus is found to be more efficient in treatment of pharmaceutical industry effluent waste water than hydrilla.

Keywords - aquatic plants, pharmaceutical effluent, waste water, water lotus, hydrilla.

Submission: March 26, $2014 \quad$ Correction: June 4, $2014 \quad$ Accepted: August 8, 2014

Doi: $10.12777 /$ ijse.7.2.100-105

[How to cite this article: Mukherjee, S. and Chatterjee, S. 2014. Assessment of Nelumbo nucifera and Hydrilla verticillata in the treatment of pharmaceutical industry effluent from 24 Parganas, West Bengal, International Journal of Science and Engineering, 7(2),100-105. Doi: 10.12777/ijse.7.2.100-105]
\end{abstract}

\section{INTRODUCTION}

Earth is covered by almost $70 \%$ water. Fresh-water content of this total available water of the earth is only $3 \%$ which comprises of icecaps, glaciers, groundwater and surface water. Only $0.3 \%$ of this surface water is available for human use like agriculture, household and drinking, industry, etc. in the form of lakes, swamps and rivers. Modern technology, global industrialization and unhygienic lifestyle have lead to a serious problem of pollution in freshwater resources like lakes, rivers and swamps [1]. Industrial effluents contribute to the inorganic pollution due to addition of waste chemicals. Anthropological influences like domestic liquid discharge, agricultural wastes, organic industrial wastes, etc. provides adequate nutrients in dissolved state for growth of pathogenic bacteria, and algae and also which interferes in beneficiary use of these natural supplies of freshwater. Rivers, lakes and other freshwater bodies encounter a serious environmental problem of eutrophication due to excess deposition of phosphorus deduced from various human activities [2]. Pharmaceutical industry effluents add up to the existing contamination of freshwater bodies which can cause acute water pollution and other environmental hazards.

Aquatic plants have been used to recover and recycle these waste waters and use them for agricultural and industrial purpose if not for household and domestic use. Low cost, easy maintenance and the ability to assimilate nutrients and sediment the inorganic chemicals makes the 
aquatic plant system a promising domestic prospect for waste water management [1]. Though there are ponds built with aquatic plant system for treatment of municipal and industrial waste water, the main challenge lies in availability of large lands, authenticity of removal of pathogenic bacteria by the aquatic plants and the choice of aquatic plants. Water hyacinth and dry hyacinth are already used for this purpose in the tropical areas. Macrophytes plays prominent role in recycling or removal of heavy metal contaminants and microbes [3]. Surface floating plants uptake heavy metal through their roots whereas leaves as well as roots of submerged plants participate in this phenomenon. The emergent plants or macrophytes influence metal storage indirectly by modifying the substratum through oxygenation, buffering $\mathrm{pH}$ and adding organic matter [4]. It has been reported earlier that almost $78 \%$ to $91 \%$ removal of BOD, reduction of nitrogen from 30.8 to $9.8 \mathrm{mg} / \mathrm{l}$ and phosphate from 14.9 to $9.6 \mathrm{mg} / \mathrm{l}$ were observed using emergent macrophytes Typha latiofolia and Phragmites carka [5]. It is reported that Hydrilla sp. has better removal efficiency when compared to Salvinia sp. [6] and is an excellent biosorbent for treating waste water contaminated with low concentration of cadmium [7]. There are many other potential aquatic plants which can be used in this respect but lack of investigation and reports in their support have not allowed doing so. This study has been carried out with two unconventional aquatic plants, water lotus (Nelumbo nucifera) and hydrilla (Hydrilla verticillata) with an aim to investigate their efficiency in treatment of pharmaceutical industry effluents. It has already been reported that water lotus is more efficient than hydrilla in treatment of domestic and municipal waste water [8]. Water lotus is a surface floating aquatic plant, has several other economical uses, for example, its stems and rhizomes as fresh vegetables, seeds as medicines, flowers as religious ornaments, etc [9]. Hydrilla is a perennial submerged plant that has been used as an animal feed, decorate aquariums [10] and has been reported as an efficient agent for removal of dissolved nitrogen and phosphorus [11].

Table 1: Performance of aquatic plant system treating pharmaceutical industry wastewater.

\begin{tabular}{|l|c|c|c|}
\hline \multirow{2}{*}{ Parameters of Analysis } & \multicolumn{3}{|c|}{ Pharmaceutical Industry Effluent } \\
\cline { 2 - 4 } & Control & Water Lotus & Hydrilla \\
\hline $\mathrm{pH}$ & 9.25 & 7.1 & 8.75 \\
\hline Solid Suspension (mg/l) & 3436 & 1291 & 1604 \\
\hline $\mathrm{BOD}_{5}(\mathrm{mg} / \mathrm{l})$ & 8.32 & 3.64 & 6.52 \\
\hline $\mathrm{NH}_{3}-\mathrm{N}(\mathrm{mg} / \mathrm{l})$ & 0.71 & 0.06 & 0.025 \\
\hline MPN Index/100 ml & $>1100$ & 28 & 75 \\
\hline Coliform Test & Positive & Negative & Negative \\
\hline
\end{tabular}

\section{MATERIALS AND METHODS}

\subsection{Materials}

Potassium hydrogen phthalate, Potassium dihydrogen phosphate, Disodium hydrogen phosphate, Sodium borate decahydrate, Manganous sulphate, Sulphuric acid, Sodium hydroxide, Sodium iodide, Sodium azide, Salicylic acid, Starch, Sodium thiosulphate, Potassium bi-iodate, Phenol, Ethyl alcohol, Sodium nitroprusside, Trisodium citrate, Sodium hypochlorite and Ammonium chloride were all procured from SRL. Lactose broth and EMB agar was bought from HIMEDIA.

\subsection{Sample Collection}

Water samples of pharmaceutical industry wastewater were collected from the rural areas of 24 parganas, West Bengal. Water lotus and Hydrilla were collected local from nursery (Figure 1).

\subsection{Determination of $\mathrm{pH}$}

The electrode of the $\mathrm{pH}$ meter was rinsed properly with double distilled water and then standardized using $0.05 \mathrm{M}$ Potassium hydrogen phthalate, $\mathrm{pH} 4.0$ followed by $0.01 \mathrm{M}$
Borax buffer, pH 9.0. The electrode was again rinsed with double distilled water and then dipped into the water sample to check their $\mathrm{pH}$. Phosphate buffer of $\mathrm{pH} 7.0$ was used as a reference buffer [12].

\subsection{Solid Suspension of water samples}

The water sample was filtered using pre-weighed Whatman filter paper. The solid remains were air dried first along with the filter paper and then again weighed. The final weight obtained was then deducted from the initial weight to determine the amount of solid suspension of the water sample [13].

\subsection{Determination of Biological Oxygen Demand $\left(\mathrm{BOD}_{5}\right)$}

The water sample was collected in BOD bottles and to it, $1 \mathrm{ml}$ of manganous sulphate was added followed by $1 \mathrm{ml}$ of alkali-iodide-azide. The bottles were capped so that the solution remains bubble free and mixed properly. Brown flakes of manganous hydroxide were allowed to settle down as precipitate. $1 \mathrm{ml}$ of concentrated sulphuric acid was added and mixed properly to dissolve the precipitate completely. The solution was then titrated against sodium thiosulphate in presence of iodine using starch solution as 
an indicator. Molarity of sodium thiosulphate was calculated using the formula:

$M=(20 \times 0.0126) / V ;$ where,$V=m L$ of thiosulphate used. Amount of dissolved oxygen (DO) was calculated using the formula:

$\mathrm{DO}(\mathrm{mg} / \mathrm{l})=(\mathrm{V} \times \mathrm{M}) / 0.025$; where, $\mathrm{M}=$ molarity of thiosulphate titrant.

In another set of black BOD bottles, the water sample collected was kept for five days in dark at room temperature. After incubation the samples was treated as described above and DO was calculated. To determine the BOD value the following formula was used [14]: $\mathrm{BOD}_{5}=$ DO of Day $1-$ DO of Day $5(\mathrm{mg} / \mathrm{ml})$.

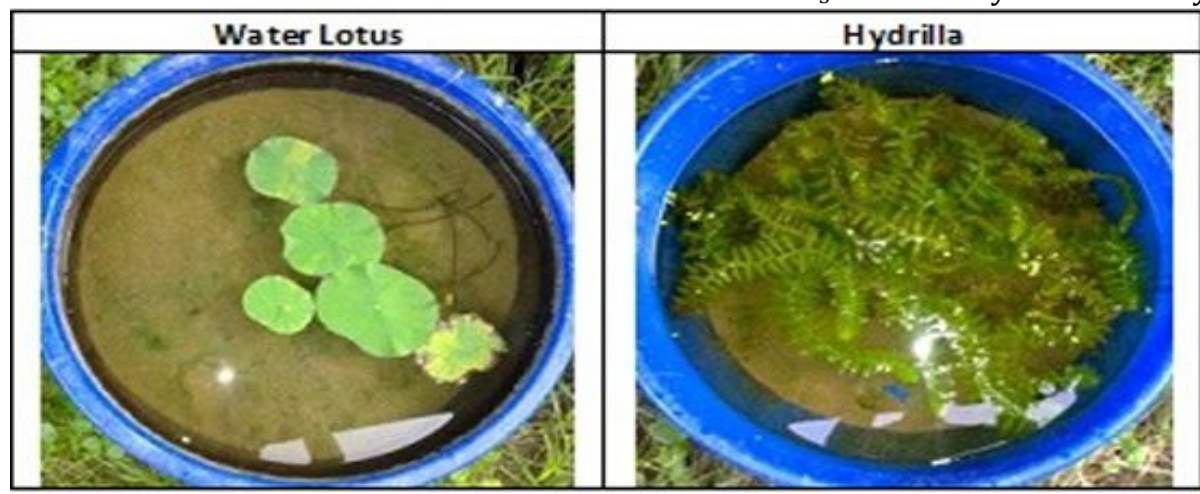

Figure 1: Maintenance of water lotus and hydrilla in laboratory conditions.

\begin{tabular}{|c|c|c|}
\hline Control & Water Lotus & Hydrilla \\
\hline & &
\end{tabular}

Figure 2: Solid Suspension of untreated (Control) and aquatic plants (water lotus and hydrilla) treated pharmaceutical industry effluent waste water samples.

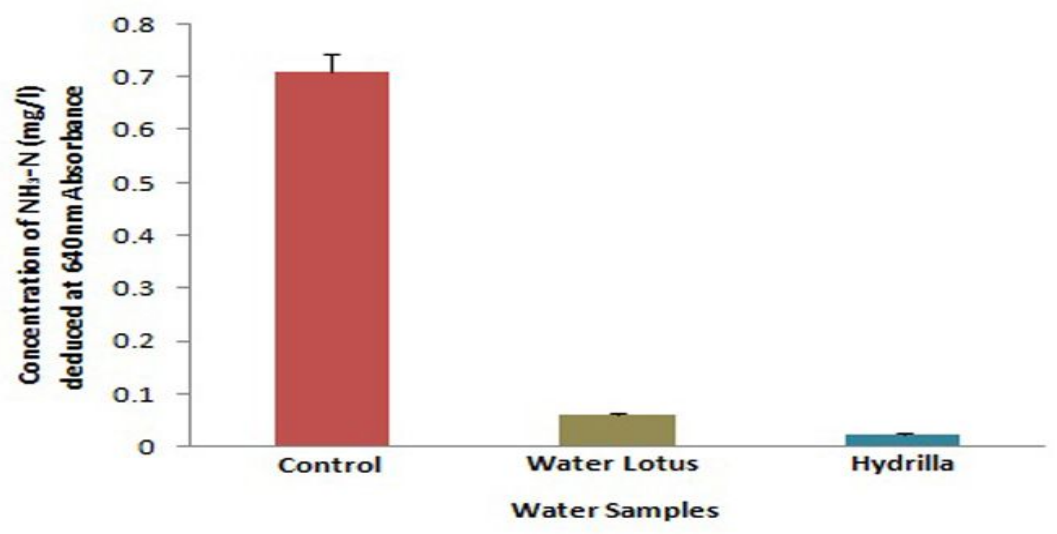

Figure 3: Ammonia - Nitrogen Assay of untreated (Control) and aquatic plants (water lotus and hydrilla) treated pharmaceutical industry effluent waste water samples. 


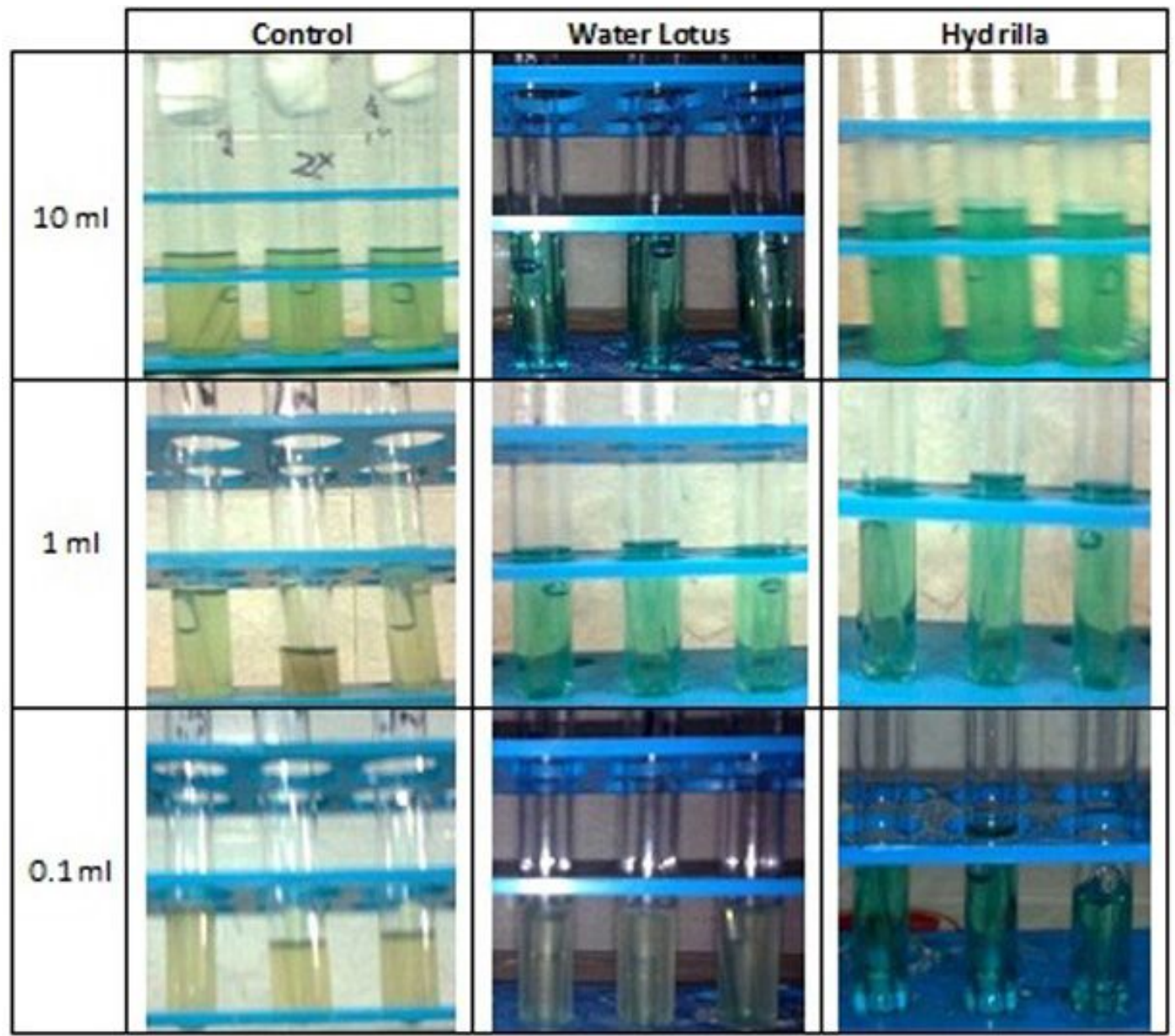

Figure 4: Most Probable Number of untreated (Control) and aquatic plants (water lotus and hydrilla) treated pharmaceutical industry effluent waste water samples.

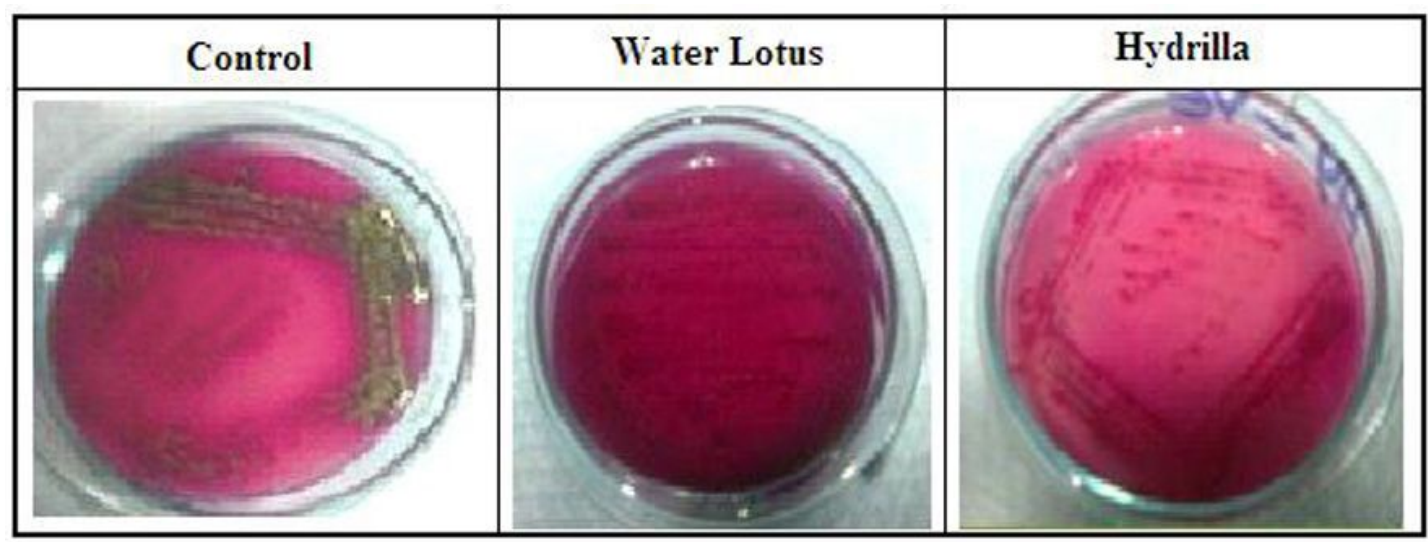

Figure 5: Coliform test of untreated (Control) and aquatic plants (water lotus and hydrilla) treated pharmaceutical industry effluent waste water samples. 


\subsection{Ammonia - Nitrogen $\left(\mathrm{NH}_{3}-\mathrm{N}\right)$ assay}

$25 \mathrm{ml}$ of water sample was taken in a bottle and to it $1 \mathrm{ml}$ phenol, $1 \mathrm{ml}$ sodium nitroprusside and $2.5 \mathrm{ml}$ of oxidizing agent ( $100 \mathrm{ml}$ alkaline citrate $+25 \mathrm{ml}$ sodium hypochlorite) were added and mixed properly. It was then kept at room temperature for 1hour for color development. Spectroscopic analysis of the water sample at $640 \mathrm{~nm}$ was done to deduce the concentration of $\mathrm{NH}_{3}-\mathrm{N}$ liberation by plotting a standard solution graph having parameters of absorbance of sample vs. concentration of $\mathrm{NH}_{3}-\mathrm{N}$ [15].

\subsection{Most Probable Number (MPN) and Coliform test}

$10 \mathrm{ml}$ of lactose broth were taken in three sets of test tubes, each set having 3 test tubes. $10 \mathrm{ml}, 1 \mathrm{ml}$ and $0.1 \mathrm{ml}$ of water sample were added to the three sets of test tubes and kept for 24 hours incubation at $37^{\circ} \mathrm{C}$. If accumulation of gas is occurs after incubation, it confirms the positive test for presumptive test of MPN [16]. Tubes that have shown gas production were then further processed for confirmed test to determine the presence of coliforms. Water sample from the tubes were inoculated in EMB agar and incubated for 24 hours at $37^{\circ} \mathrm{C}[17]$.

\section{RESULTS}

\subsection{Determination of $\mathrm{pH}$ and solid suspension}

Pharmaceutical industry effluent before treatment with the aquatic plants showed high alkaline pH $(\approx 9.25)$ which became almost neutral after treatment with water lotus $(\approx$ 7.1 ) and lesser alkaline $(\approx 8.75)$ after exposure to hydrilla. There was a distinct decline in the weight of solid suspension of waste water sample after treatment with the two aquatic plants (Table 1, Figure 2) when compared to its untreated counterpart.

\subsection{Determination of Biological Oxygen Demand $\left(\mathrm{BOD}_{5}\right)$}

$\mathrm{BOD}_{5}$ is a measure of consumption of oxygen by organic matter and associated microorganisms present in the water over a period of five days. Treatment of pharmaceutical industry effluent with water lotus revealed greater deduction in $\mathrm{BOD}_{5}$ than hydrilla when compared to the untreated water sample (Table 1).

\subsection{Determination of the concentration of $\mathrm{NH}_{3}-\mathrm{N}$ liberation}

The wastewater sample showed significant decrease in the concentration of $\mathrm{NH}_{3}-\mathrm{N}$ after treatment with water lotus than hydrilla when compared to the untreated water sample (Table 1, Figure 3).

\subsection{MPN and Coliform test}

MPN index $/ 100 \mathrm{ml}$ of untreated pharmaceutical industry effluent was very high $(>1100)$ which diminished significantly to 21 and 43 after treatment with water lotus and hydrilla respectively. Coliform test exhibited positive results for untreated water sample which after treatment with the two aquatic plants showed negative results (Table 1, Figure 4 and Figure 5).

\section{DISCUSSION \\ 4.1 $\mathrm{pH}$ and Solid Suspension}

Pharmaceutical industry effluent has shown a high alkaline $\mathrm{pH}$ which indicates waste materials of pharmaceutical industry of 24 parganas contains excessive use of alkaline byproducts. The weight of solid suspension is also an indicative of contamination with solid wastes from the pharmaceutical industry. Treatment of the effluent with water lotus made the $\mathrm{pH}$ almost neutral and though hydrilla was not very efficient. There was a significant reduction in the weight of solid suspension. This is an indicative that water lotus and hydrilla to some extent both are capable of diminishing the $\mathrm{pH}$ and absorb the solid suspensions.

\subsection{Biological Oxygen Demand $\left(\mathrm{BOD}_{5}\right)$}

Biochemical oxygen demand is a measurement of dissolved oxygen needed by aerobic biological organisms in water bodies to break down organic material present in a given water sample at certain temperature over a time period of five days. It is widely used as an indication of the organic quality of water [18]. BOD 5 study unveils a distinct decline in the treated effluent compared to the untreated sample. This is an indicative of the fact that since the water samples are incubated in dark bottles in dark chambers, the oxygen demand of the pharmaceutical effluent gets diminished as the living organisms of the habitant are unable to use the dissolved oxygen due to absence of light, hence the sharp decline in $\mathrm{BOD}_{5}$ value.

\subsection{Concentration of $\mathrm{NH}_{3}-\mathrm{N}$ liberation}

The concentration of $\mathrm{NH}_{3}-\mathrm{N}$ of untreated waste water is a clear indicative that it is excessively polluted with nitrogenous organic materials. The final $\mathrm{NH}_{3}-\mathrm{N}$ concentration of the treated effluent water is at par indicating that aquatic plants are well capable of controlling $\mathrm{NH}_{3}-\mathrm{N}$ pollution in domestic freshwater bodies.

\subsection{MPN and Coliform test}

MPN Index/100 $\mathrm{ml}$ is a presumption of presence of coliform bacteria. To confirm the presence of coliforms EMB agar plates are inoculated with positive presumptive samples. If colonies obtained shows green metallic sheen, it confirms the presence of E.coli, which is found in human fecas, a positive test for coliforms. If large pink colonies appear, it confirms the presence of Eaerogenes, which is widely distributed in nature, a negative test for coliforms [19]. The MPN Index $/ 100 \mathrm{ml}$ of untreated water sample gave a clear view that it was highly contaminated with coliform bacteria. 
Further coliform analysis using EMB agar plates confirmed the presence of coliforms (mainly E.coli as green metallic sheen was observed) indicating fecal contamination. After treatment with aquatic plants, it was observed that MPN Index/100 $\mathrm{ml}$ deduced to very lower range in the effluent water with better efficiency in case of water lotus. Coliform test of the treated water sample confirms the removal of coliforms as only large pink colonies were observed.

\section{CONCLUSION}

Based on the results obtained, the water lotus system showed better efficiency in treatment of pharmaceutical industry effluent wastewater than the hydrilla system. Hydrilla exhibited less efficiency in effluent polishing. A treatment system with water lotus may be a potential alternative as an aquatic plant system, not only for domestic wastewater treatment [8] but also for treating pharmaceutical effluents.

\section{ACKNOWLEDGMENTS}

The authors are grateful to the home institute for providing space and resources to carry out this work.

\section{REFERENCES}

[1] Boyd, C.E., (1970) Vascular aquatic plants for mineral nutrient removal from polluted water. Econ. Bot, 24(1): 95-103.

[2] Onoda, H., Fukatsu, R., and Tafu, M., (2013) Reaction of sea shells with resemble phosphorus wastewater and application of products. J. Environ. Occup. Sci, 2(2):71-76.

[3] Pip, E., and Stepaniuk, J., (1992) Cadmium, copper and lead in sediments and aquatic macrophytes in the lower Nelson River system, Manitoba, Canada. L Interspecific differences and macrophyte-sediment relations. Arch. Hydrobiol, 124(3): 337-335.

[4] Dunbabin, J.S., and Bowmer, K.H., (1992) Potential use of constructed wetlands for treatment of industrial wastewaters containing metals. Sci. Total Environ, 111: 151-168.
[5] Juwarker, A.S., Oke, B., Juwarkar, A., and Patnaik, S.M., (1995) Domestic wastewater treatment through constructed wetland in India. Water Sci. Technol, London, 32(3): 291-294.

[6] Elankumaran, R., Raj, M.B., and Madhyastha, M.N., (2003) Biosorption of copper from contaminated water by Hydrilla verticillata Casp. and Salvinia sp. Environmental News Sources, Green Pages.

[7] Bunluesin, S., Kruatrachue, M., Pokethitiyook, P., Upatham S., and Lanza, G.R., (2007) Batch and Continuous packed column studies of cadmium biosorption by Hydrilla verticillata biomass. J. Biosci. Bioeng, 103: 509-513.

[8] Kanabkaew, T., and Puetpaiboon, U., (2004) Aquatic plants for domestic wastewater treatment: Lotus (Nelumbo nucifera) and Hydrilla (Hydrilla verticillata) systems. Songklanakarin J. Sci. Technol, 26(5): 749-756.

[9] Yi, Y., Lin, C.K., and Diana, J.S., (2002) Recycling pond mud nutrients in integrated lotus-fish culture. J. Aquaculture, 212: 213-226.

[10] Polprasert, C., (1996) Organic Waste Recycling: Technology and Management: $2^{\text {nd }}$ ed. John Wiley \& Sons, Chichester.

[11] Vincent, W.J., (2001) Nutrient partitioning in the upper Canning River, Western Australia, and implications for the control of cyanobacterial blooms using salinity. J. Eco. Eng, 16: 359-371.

[12] Franson, M.A., (1975) Standard Methods for the Examination of Water and Wastewater $14^{\text {th }}$ edition, pp. 406-407. APHA, AWWA \& WPCF.

[13] Franson, M.A., (1975) Standard Methods for the Examination of Water and Wastewater $14^{\text {th }}$ edition, pp. 89-98. APHA, AWWA \& WPCF.

[14] Clesceri, L.S., Eaton, A.D., and Rice, E.W., (2005) Standard Methods for Examination of Water \& Wastewater Method 5210B. Washington, DC: American Public Health Association, American Water Works Association, and the Water Environment Association.

[15] Solórzano, L., (1969) Determination of ammonia in natural waters by the phenol hypochlorite method. Limnol. Oceanogr, 14(5): 799801.

[16] Sutton, S., (2010) The Most Probable Number Method and Its Uses in Enumeration, Qualification, and Validation. J. Validation Tech, 16(3): 35-38.

[17] Lal, A., and Cheeptham, N., (2007) Eosin-Methylene Blue Agar Plates Protocol. American Society for Microbiology.

[18] Sawyer, C.N., McCarty, P.L., and Parkin, G.F., (2003) Chemistry for Environmental Engineering and Science $5^{\text {th }}$ ed. New York: McGrawHill.

[19] Bacterial Examination of Water. (1993) American Water Work Association. 